\title{
Is Xi Jinping the Reformist Leader China Needs?
}

Jean-Pierre Cabestan

\section{(2) OpenEdition}

\section{Journals}

\section{Electronic version}

URL: http://journals.openedition.org/chinaperspectives/5969

DOI: 10.4000/chinaperspectives.5969

ISSN: 1996-4617

\section{Publisher}

Centre d'étude français sur la Chine contemporaine

\section{Printed version}

Date of publication: 1 October 2012

Number of pages: 69-76

ISSN: 2070-3449

\section{Electronic reference}

Jean-Pierre Cabestan, «Is Xi Jinping the Reformist Leader China Needs? », China Perspectives [Online], 2012/3 | 2012, Online since 01 October 2015, connection on 15 September 2020. URL : http:// journals.openedition.org/chinaperspectives/5969 


\title{
Is Xi Jinping the Reformist Leader
}

\section{China Needs?}

\author{
JEAN-PIERRE CABESTAN
}

ABSTRACT: In autumn 2012, following the 18th Congress of the Chinese Communist Party (CCP), Xi Jinping is to succeed Hu Jintao as General Secretary of the Party and also, in all probability, as Chairman of the Central Military Commission, where he has been second-in-command since 2010. In March 2013, he is set to become President of the People's Republic of China. Born into the political elite, he enjoys a great deal of support in the Nomenklatura. Having governed several coastal provinces, the current Vice-President is thoroughly acquainted with the workings of Party and state. He also has support within the Army, where he spent a short time at the beginning of his career. In addition, in recent years, he has acquired significant international experience. Urbane and affable, $\mathrm{Xi}$ is appreciated for his consensual approach.

Nonetheless, $\mathrm{Xi}$ is taking charge of the country at a particularly delicate time. China is having to adopt an alternative growth model whilst the government is struggling with powerful economic and regional feudalities. The Bo Xilai affair has highlighted the weakening of the central government, the corruption of the elites, and deep-rooted ideological differences within the Party machine that are damaging the political legitimacy of the regime and endangering its stability.

As a result, Xi must not only reunify the Party leadership and machine but also establish his authority over all the country's civil and military institutions. His style and charisma will help him. But his success will also and above all depend on his ability to form a united coalition set on reform and capable of dismantling the privileges acquired by the regime's many bosses. The CCP needs a leader who is both strong and courageous. Is Xi such a man? Perhaps.

L ittle is known about $\mathrm{Xi}$ Jinping, the Chinese leader who is to take over from Hu Jintao as General Secretary of the Central Committee of the Communist Party this autumn, and the following spring as President of the People's Republic of China (PRC). Admittedly, since he was born into the Party, the biography of this representative of the "red aristocracy" is scarcely difficult to trace. He is the son of CCP veteran Xi Zhongxun and his career and gradual rise to the top are familiar to all. He has spoken very little, however, and on those occasions when he has put forward ideas, they have always proved to be completely in tune with the political line of the moment. It is particularly difficult in these circumstances to identify his program and still less the slant he might give to the reforms and policies currently underway in the People's Republic. His style and behaviour in public and international meetings are a little easier to understand. It would be unwise, however, to draw too many conclusions, since these would necessarily be over-hasty and impressionistic.

We must therefore base our arguments on the solid information we possess, not only on Xi but also on the current organisation of the institutions, and draw a certain number of logical conclusions on the role he will be called upon to play at the end of the CCP's 18th Congress, as leader of the world's second largest economy and most populous country as well as one of the most authoritarian polities. In short, our hypothesis is that he is neither a reformer nor a conservative but that circumstances will probably oblige him to lean towards one rather than the other.

\section{Biography and career of Xi Jinping}

\section{An early life full of incident}

Xi Jinping's official biography is fairly representative of the "princelings" (taizidang) whose parents were persecuted during the Cultural Revolution, then reinstated. Born on 1 June 1953 in Beijing, Jinping is the son of $\mathrm{Xi}$ Zhongxun, who was born in Fuping in Shaanxi, future veteran of the Communist Revolution and close collaborator of Prime Minister Zhou Enlai in the central government of the People's Republic. The second of $\mathrm{Xi}$ Zhongxun's second wife's four children, Jinping received a superior type of education. At a very young age, after his father was appointed vice-premier (1959), he moved with his family to Zhongnanhai, seat of Communist power since 1949.

However, his father saw his career interrupted, not in 1966 during the upheavals of the Cultural Revolution like many other leaders close to Liu Shaoqi and Deng Xiaoping (including, for example, Peng Zhen and Bo Yibo), but in 1962. For having given his support to the publication of a biography of Liu Zhidan, head of the Yan'an guerrilla base that with Gao Gang welcomed Mao Zedong and his army after the Long March in 1935, Xi Zhongxun was accused of leading an "anti-Party" group. This project was seen by Mao as veiled support for the rehabilitation of Gao Gang, who had been ousted in 1954. But more generally, scarcely two years after the great famine brought about by the Great Leap Forward (30 to 46 million victims), Mao began to distance leaders he saw as too moderate. Consolidating the powers of the People's Liberation Army (PLA), already led by Marshal Lin Biao, and of the political police, which had been taken in hand by the sinister Kang Sheng, Mao decided at the same time to reintroduce "class struggle" and, as a consequence, to launch the "socialist education movement."

In 1962, Xi Zhongxun was thrown into prison - this was only known much later - and his family had to leave Zhongnanhai. Four years later, Zhongxun's wife was sent to a labour camp in the countryside. Jinping's school was closed. Left to his own devices, he took advantage of the prevailing anarchy and desertion of the libraries to read anything he came across. Soon afterwards however, at the age of 14 , Jinping was sent to Liangjiahe, a production brigade (village) in the Yanchuan district to the north of Shaanxi near his 
father's former guerrilla base. Living conditions there were difficult. Jinping was looked upon with suspicion by the villagers, who found at first that he lacked enthusiasm for the task in hand. After several months, he fled and returned to Beijing. There he was arrested and sent for a time to a labour camp before returning to Liangjiahe. This time, according to his official biography, Jinping set to work, learnt how to work in the fields, and avoided complaining, unlike many "young educated people" (zhiqing) deported to the countryside. In short, he adapted, integrated, and managed to gain the respect of the peasants, all the more so since he displayed initiative and ingenuity, introducing, for example, biogas production into the village using fermented organic animal matter. But like many other young city-dwellers sent to work in the fields (see Dai Sijie's Balzac and the Little Chinese Seamstress, 2000), he arrived bearing a heavy box of books and continued to educate himself.

Jinping was nonetheless not completely protected from political campaigns. Like many leaders' sons, he was asked to denounce his parents by those promoted to positions of responsibility as a result of the Cultural Revolution. The anecdote circulating in China since before the fall of Bo Xilai in March-April 2012 is that unlike Bo, Jinping avoided accusing his father, arguing that he had no knowledge of his ideas and actions since he had been separated from him for too long.

The official story likewise tells us that despite the persecution of his family (his half-sister is thought to have been killed at this time), Jinping never lost confidence in the Party. He tried unsuccessfully to join the Communist Youth League, ante-chamber of the CCP, at least eight times. He finally succeeded in 1971 after inviting the local Party secretary to share some fried eggs and mantou (steamed bread) in his cave, a type of dwelling still common on the loess plateau of northern Shaanxi. (1) Can the virtues of corruption already be seen here? Be that as it may, after the Lin Biao affair (1971), although Xi Zhongxun remained in detention, at least officially, his family gradually emerged from the ranks of the untouchables, and in 1974, a year after Deng Xiaoping was rehabilitated for the first time, Jinping managed to join the Party. Shortly afterwards, elected by an overwhelming majority by the villagers, he became secretary of the brigade's Party committee. However, the following year, in 1975, this same committee recommended him for a place at university. At the time, this was the formal sine qua non condition for gaining access to higher education. It was therefore on the instructions of the CCP that he entered Tsinghua University, where he studied chemical engineering, a discipline he was never destined to exercise.

\section{An exemplary but privileged cursus honorum}

It was not until the death of Mao (1976), the fall of the "Gang of Four" (Mao's wife and other radicals produced by the Cultural Revolution), and the second come-back of Deng that Xi Zhongxun returned to public life. Rehabilitated in 1978, he soon afterwards became Party secretary of Guangdong Province, where from 1979 onwards he launched the first economic reforms and, most importantly, set up the special economic zones of Shenzhen and Zhuhai. This major political development had a determining influence on Xi Jinping's career. Indeed, his father (who died in 2002) used his contacts to place his son as secretary (mishu) both in the State Council's Office of General Affairs and to his former comrade Geng Biao, then General Secretary of the CCP's Central Military Commission, presided over from December 1980 to November 1989 by none other than Deng Xiaoping. Xi Jinping than served as an officer in the PLA, which according to his official biography inculcated in him "a special affection for the Army." (2) More importantly, since it placed him in immediate proximity to the country's main leaders, for Xi Jinping, as for many other ambitious young cadres of his generation, his position as mishu acted as an effective springboard to his career.

It was around this time that Xi jinping married Ke Lingling, whose father was the Chinese ambassador to Great Britain, and began to live in a privileged environment once again. The young couple divorced three years later, however, and it was then that Jinping's political career took a more provincial and strategic turn. From 1982 onwards, he accepted a long series of local postings that gave him experience of both rural realities and the country's rapid urbanisation and industrialisation. He was appointed deputy secretary and then secretary of Zhengding District, near Shijiazhuang in Hebei. In 1985, Xi Jinping was transferred to Fujian, thanks once again to his father, who enjoyed a close relationship with Xiang Nan, then governor of the province. ${ }^{(3)}$ Xi was to remain in Fujian for 17 years. Appointed deputy mayor of Xiamen in 1985, he participated until 1988 in the expansion of Fujian's most dynamic metropolis before being appointed to run Ningde, a rural prefecture in a mountainous area northeast of Fujian, near Zhejiang Province. It was also in 1985 that Xi jinping made his first visit, as part of an official delegation, to the United States and in particular Muscatine, lowa, to observe and study American agriculture. He made a return "pilgrimage" there in February 2012, this time on his first visit to America as Vice-President of the Republic.

In 1986, aged 33 and hoping to remarry, Xi Jinping went on a blind date with the famous PLA singer Peng Liyuan, who was later promoted to the rank of major general (shaojiang). Once again, the Chinese media made much of the conversation that Liyuan claims the two young people had: jinping apparently asked Liyuan what type of songs she sang, on the pretext that he watched very little television. Be that as it may, it would be true to say that at the time, the new Mrs. Xi Jinping was far more famous than her husband. The couple had one child, a daughter named Xi Minze born in 1992 and currently a student at Harvard University. In another and more indirect way, this marriage established a second privileged relationship between $\mathrm{Xi}$ and the PLA. ${ }^{(4)}$

In 1990, Xi Jinping finally relocated to Fuzhou, the provincial capital, where he initially spent three years as president of the municipal People's Congress, a formal, marginal structure, as well as taking over the directorship of the local Party school before going on to become secretary of the municipality's Party committee and consequently sitting on the provincial CCP Standing Committee. In 1996, he abandoned these posts in Fuzhou and concentrated on his work as deputy secretary of Fujian, of which he became governor in 1999. It is undoubtedly at that time that he came to be seen as destined for a career at the national level. Indeed, during the $15^{\text {th }}$ CCP Congress in October 1997, he was elected alternate member of the Central Committee whilst still only secretary of Fuzhou. He was 43.

Fujian, and in particular the special economic zone of Xiamen, was the scene of many a corruption scandal in the 1990s, the most well-known

1. Los Angeles Times, 11 February 2012.

2. Robert Lawrence Kuhn, How China's Leaders Think: The Inside Story of China's Reforms and What This Means for the Future, Singapore, Willey, 2009, p. 430. Xi's biography as told in this book is quasi-official. Indeed, Kuhn makes no secret of his admiration for the People's Republic of China.

3. Wu Ming, Xi Jinping zhuan (About Xi Jinping), Hong Kong, Xianggang wenhua yishu chubanshe, 2008, pp. 122-123.

4. For further information on the Xi-Peng couple, see Kuhn, op. cit., pp. 432-436. 
being the Yuanhua affair, named after the company run by businessman Lai Changxing, who was implicated in large-scale smuggling activities from Hong Kong with the complicity of many local cadres and the PLA, in particular the Navy. In February 2000, soon after Lai fled to Canada (where he managed to remain until 2011 before being extradited to China), ${ }^{(5)}$ Xi Jinping and the provincial Party secretary at the time, Chen Mingyi, were summoned to Beijing by Jiang Zemin, Zhu Rongji, and $\mathrm{Hu}$ Jintao to report on this scandal. ${ }^{(6)}$ The episode does not seem to have affected Xi Jinping, who in 2002 was promoted to governor and soon afterwards Party secretary of the big neighbouring province of Zhejiang. Certain sources indicate that $\mathrm{Xi}$ may well have helped put an end to the smuggling. ${ }^{(7)}$ However, some of these decisions were criticised, among them the construction of a new airport at Fuzhou and the redevelopment of the centre of the provincial capital with the help of Hong Kong tycoon Li Kai-shing. Furthermore, several of Xi's direct subordinates were involved in corruption. ${ }^{(8)}$

Throughout these years, $\mathrm{Xi}$ Jinping was said to have maintained a simple, even austere, lifestyle, very different from other children of the red aristocracy and other ambitious young administrators of his generation. He drank very little, was not known as a philanderer, and continued to go to work on a bicycle as though he already considered himself destined for a future as a national figure.

In Fujian, Xi jinping also acquired a reputation as a realistic, efficient, and relaxed Party secretary, conscious of the need for China to move towards a market economy and benefit from foreign investment. It was at this time that he became known for his motto "Do it immediately!" (mashang jiu ban!), intended to defeat his subordinates' tendency towards procrastination. It has also been said that he accelerated reforms that required government departments to place themselves at the service of society and business. He was one of the first to surround himself with advisors, drawn from academia and from outside the bureaucracy. ${ }^{(9)}$ Since Fujian Province faces Taiwan, Xi considered it an ideal place to develop links with Taiwanese business people, who saw him as a pragmatic contact despite the military and political tensions between Beijing and Taipei, especially during the 1995-1996 missile crisis. By the same token, he familiarised himself with policies regarding Taiwan. He multiplied - and even cultivated, according to certain sources - contacts with PLA leaders from the military region of Nanjing, on which Fujian depended. (10)

Nonetheless, as part of his meticulous preparations for a political future, he found time between 1998 and 2002 to obtain a doctorate in law at the Faculty of Humanities of Tsinghua University. The largely political character of this degree should be regarded with circumspection, however, given that according to his official biography Xi mainly studied Marxist theory and "ideological and political education." (11)

\section{Zhejiang and Shanghai: Decisive staging posts}

In 2002, Xi Jinping was transferred to Zhejiang, where he spent five years, first as deputy Party secretary and interim governor, then very soon after as secretary of this big coastal province - the richest in China in terms of average standard of living - until March 2007. It was in these posts that Xi consolidated his track record as a modernising, reforming administrator, whilst at the same time developing his international image. In October 2002 , during the CCP's $16^{\text {th }}$ Congress, he became a full member of the Central Committee. As Zhejiang's boss, Xi promoted certain policies that give an indication of his opinions and priorities.
He was said, for example, to favour private enterprise, the main source of new jobs in China and pillar of the province's economy $(500,000$ of its 680,000 companies are private). However, an inclination cultivated partly for the purposes of public relations must be treated with caution. Admittedly, like other leaders (Li Keqiang and Jia Qinglin), Xi Jinping had consistently supported the pan-Chinese Federation of Industry and Commerce. This semi-governmental organisation stimulates, but at the same time controls, the emergence of the private sector, notably through inciting each company to establish a CCP Committee, and by co-opting the owners of these companies into the Party and formal state organisations (popular assemblies, consultative conferences) in accordance with the new policy recommended by Jiang Zemin from 2001 onwards (the "Three Represents" or "three types of representativeness"). In reality, as he indicated several times, Xi leaned towards the integration of the public and private sectors. The private Wahaha Group, based in Hangzhou and partly controlled by this municipality, is the best example of this type of integration (for which the French company Danone paid the price). The entrepreneurial approach that characterised what was called the Zhejiang Model therefore falls far short of privatisation of the economy, except perhaps in the Wenzhou region, a special case. Moreover, although Zhejiang's prosperity enabled it to abolish the hukou (residence permit) system, Xi stuck closely to Hu Jintao's political line, promising a narrowing of the income gap, the maintenance of "harmony" between entrepreneurs and migrant workers, and improvements in municipal governance. ${ }^{(12)}$

He was therefore a moderniser. He tried to improve and simplify the administrative machine, and according to his hagiographies, to make the processes of selection and promotion of government cadres more transparent, introduce forms of external control, and battle abuses of intellectual and industrial property rights. ${ }^{(13)} \mathrm{He}$ is also credited with publicising local budgets more widely and taking greater account of public opinion, even though these experiments, notably in the town of Wenling, began before his arrival in Zhejiang. ${ }^{(14)} \mathrm{He}$ travelled a great deal to promote his province abroad, in the United States and elsewhere.

Yet he was also a realist, conscious of environmental issues, the need to upgrade industry, and conflicts between interest groups. He gave himself the objective of closing down polluting, electricity-hungry companies - even though this objective is far from being achieved - taking as his slogan "coordination and balance." Lastly, and this is important for the future of the

5. Lai Changxing was sentenced to life imprisonment on 18 May 2012. Canada agreed to his extradition on the condition that he not receive the death penalty.

6. Xiao Yu, "Fujian leaders face Beijing top brass," South China Morning Post, 18 February 2000. Chen's predecessor Jia Qinglin and his wife had long been implicated in this scandal. A protégé of Jiang Zemin, Jia was promoted in 1997 to the CCP Politburo and in 2002 to the Politburo's Standing Committee to take over the presidency of the Chinese People's Political Consultative Conference (CPPCC), from which he is to retire in March 2013. Admiral Liu Huaqing's daughter Liu Chaoying was also associated with this affair. A former Commander of the Navy, Liu was member of the CCP Politburo Standing Committee until he retired in 1997.

7. Kuhn, op. cit., p. 186.

8. Wu Ming, Xi Jinping zhuan, op. cit., pp. 173, 177, and 181.

9. South China Morning Post, 23 October 2007.

10. James Mulvenon, "Xi Jinping and the Central Military Commission: Bridesmaid or Bride?", China Leadership Monitor, no. 34, 2011

11. http://www.china.org.cn/english/MATERIAL/76256.htm and http://news.xinhuanet.com/politics/ 2010-10/18/c_12673101_2.htm (links consulted on 24 April 2012).

12. Wu Ming, Xi Jinping zhuan, op. cit., pp. 222-246.

13. Kuhn, op. cit., pp. 210-213.

14. Joe Fewsmith, "Participatory Budgeting. Development and Limitations," China Leadership Monitor, no. 29 , Spring 2009. 
centre-periphery relationship, whilst adhering to the "spirit" of central policies, he used all the leeway that his position as provincial head allowed. This leads us to believe that he will, in future, avoid asphyxiating the regional authorities with national directives, except where the supreme interests of the Party are at stake.

This being the case, in Zhejiang, conscious of an increasing number of industrial disputes, $\mathrm{Xi}$ asked the official unions operating under the direction of the Party to commit themselves more actively and in a more balanced way to resolving social tensions. This became known as the Yiwu Model after a town known for its many private companies and export market in developing countries. The aim of this model is not only to prevent the emergence of independent unions, but also to avoid (unlike Guangdong, for example) the interference of human rights NGOs in the resolution of industrial disputes. ${ }^{(15)}$

Xi Jinping's career really gathered speed when he was chosen in March 2007 to replace Chen Liangyu as Shanghai's Party secretary. Chen was the second member of the Politburo to have been unseated for corruption since the beginning of the reforms (in April 2008, he was sentenced to 18 years in prison). ${ }^{(16)}$ Xi's role in cleaning up the Fujian administration following the Yuanhua affair must have played a part in this promotion, which put him in line for a position on the CCP Politburo. Since the early 1990s, a non-written rule has made the Party secretaries of Shanghai, Beijing, and Tianjin (and since 2002, Chongqing) ex officio members of the collegial leadership of the Party and the country. ${ }^{(17)}$

Xi's time in Shanghai was short-lived - seven months - since a second dramatic turn of events, or unexpected development, in October 2007 catapulted Xi's career further forward when he was chosen by the collective leadership of the Party to succeed Hu Jintao. However, like other former bosses of Shanghai, including Wu Bangguo and Yu Zhengsheng, Xi Jinping remains a partisan of developing the leading Chinese metropolis as a "double centre," that is to say both a financial market and maritime trade platform. ${ }^{(18)}$

\section{Xi Jinping, future Chinese Number One: A man with a consensual approach?}

Xi's brief experience in Shanghai was not unrelated to his promotion. But more generally, his strength is to appear unconnected to any particular faction or opinion group, maintaining a balance worthy of Solomon between promotion of the "Three Represents" (integration of private entrepreneurs into the Party) dear to the heart of former Party General Secretary Jiang Zemin, and of the concepts of "harmonious society" and a "scientific approach to development" forged by Hu Jintao.

\section{Underlying reasons for choosing Xi}

As is well known, deep-seated differences have divided the partisans of $\mathrm{Hu}$ Jintao and Jiang Zemin over the first successor not to have been chosen by the generation of revolutionary veterans. While Deng Xiaoping was able to appoint not only his immediate successor, Jiang ( $3^{\text {rd }}$ generation of CCP leaders), but also the successor of his successor, $\mathrm{Hu}$ (4th generation), CCP leaders found themselves in uncharted waters in 2007. Amongst the potential leaders of the $5^{\text {th }}$ generation, Hu favoured Li Keqiang, a former head of the Communist Youth League, Hu's own breeding-ground. Jiang, however, persuaded the leaders and those of the Party's elders who were still ablebodied (Wan Li, Qiao Shi, Song Ping, and Admiral Liu Huaqing) to favour Xi
Jinping, a worthy representative of the red aristocracy and a likely defender of the Shanghai clique (Shanghai bang) promoted by the former General Secretary. The Party's then Number Five, Zeng Qinghong, son of the revolutionary leader Zeng San, played a key role in the promotion of his own successor, not only to the head of the CCP Secretariat and the Party's Central School, but also to the vice-presidency of the People's Republic. It was as though Zeng, too old to take first place, took his revenge by favouring a close confederate to preside over the country's destiny. ${ }^{(19)}$

Admittedly, Hu and his partisans were not completely defeated for all that. Like Xi Jinping, Li Keqiang was also promoted directly to the Standing Committee of the CCP Politburo (SCPB) and became the presumed successor of Premier Wen Jiabao. The choice of Xi nevertheless illustrates the growing nepotism of a regime that applied a non-written rule, successfully put forward by certain veterans, including Bo Yibo, Bo Xilai's father (who died in 2007), in 1992: (20) during the $17^{\text {th }}$ Congress, Xi was one of seven princelings to join the Politburo (as against three during the preceding Congress). The political (ensuring the survival of the regime) and economic (protecting the privileges accrued by the "red princes") motivations behind this worrying trend should not be underestimated. (21)

Be that as it may, in September 2010 (three, and not two years later as some observers had predicted), Xi jinping joined the Central Military Commission (CMC) of the CCP and became its vice-president. This slight delay in the "Hu Jintao precedent" (Hu was promoted to this post in 1999, that is to say two years after the $15^{\text {th }}$ Congress and a year after his election to the Vice-Presidency of the Republic) may be attributed to Hu's disgruntlement with a successor who was not his first choice. But as we will see, it would be vain to see this as an obstacle to Xi's replacement of $\mathrm{Hu}$ as president of the CMC in October 2012. And as with Hu in 1997-2002, Xi became increasingly associated with the country's national affairs and foreign policy from 2007 to 2008.

\section{$X i$ and the Party factions}

It was the new plan of succession that was to lead certain analysts such as Cheng Li of the Brookings Institute to elaborate the theory of a fundamental opposition between the "elitists," the princeling faction that included Jiang Zemin, Xi Jinping, Wang Qishan, and Bo Xilai on the one hand, and on the other, the "populist" faction of the Communist Youth League (tuanpai), represented by Hu Jintao, Li Keqiang, Li Yuanchao, and Wang Yang. (22)

15. Zou Chen, "Guarding the Territory of Labor Rights Protection: A Socialized Approach by the Yiwu Federation of Trade Unions," Master's thesis, Hong Kong Baptist University, December 2011.

16. In 1995, Beijing Party secretary Chen Xitong became the first member of the Political Bureau to be removed for corruption.

17. Wu Ming, Xi Jinping zhuan, op. cit., pp. 254-257. As a result of the Bo Xilai affair, this non-written institutional rule may be called into question during the Party's 18th Congress.

18. Kuhn, op. cit., p. 227

19. Zheng Yongnian and Chen Gang, "Xi Jinping's Rise and Political Implications," China: An International Journal, vol. 7, no. 1, March 2009. Wu Ming, Xi Jinping zhuan, op. cit., pp. 291-294.

20. Bo Yibo is said to have suggested that each Communist leader be allowed to promote one of his own children. See Cheng Li, China's Leaders: The New Generation, Lanham, MD, Rowman \& Littlefield, 2001, p. 131, quoted by François Godement, China at the Crossroads, ECFR Essay, no. 53, April 2012, p. 4.

21. See John Dotson, The China Rising Leader Project, Part 1, The Chinese Communist Party and Its Emerging Next-Generation Leaders, Washington DC, US-China Economic and Security Review Commission Staff Research Report, March 2012, pp. 31-32, and Part 3, China's Rising Leaders in the State-owned Economy, August 2012.

22. Cheng Li, "China's Fifth Generation: Is Diversity a Source of Strength or Weakness?", Asia Policy, no. 6, July 2008, pp. 53-93. See also Cheng Li, "The Battle for China's Top Nine Leadership Posts," The Washington Quarterly, vol. 35, no. 1, Winter 2012, pp. 131-145. 
Although seductive in 2007 and widely adopted because it reflects an almost perfect balance between these two "factions," this theory displays many weaknesses that must be weighed up if we want to understand and predict the choices that Xi Jinping might make once he becomes China's Number One.

It is clear that when he began to relinquish power in 2002, Jiang placed many representatives of the "Shanghai clique" (Wu Bangguo, Zeng Qinghong, and Huang Ju in the SCPB) in key posts. But he also promoted, particularly within the SCPB, loyal men who have taken other routes such as Jia Qinglin (former Fujian Party secretary) and Li Changchun (Guangdong). And since 2007, Jiang's group of partisans in the SCPB has weakened. Only Wu Bangguo (Chairman of the National People's Congress, NPC), Jia Qinglin (President of the CPPCC), and Li Changchun (in charge of propaganda) have remained. The new secretary of the Party's Central Discipline Inspection Commission, He Guogiang, and security czar Zhou Yongkang were promoted by $\mathrm{Hu}$ Jintao. 23

Secondly, the relationship between $\mathrm{Hu}$ and the League has been over-interpreted: not only did Hu not choose all the organisation's new leaders, but it has become so common to take this route - Xi Jinping is himself a product of it - that it cannot be associated with proximity to the current (and outgoing) General Secretary alone.

Lastly and above all, the opposition between elitism and populism is difficult to justify, since the new generation of Communist leaders all seem tempted to combine, in admittedly varying doses, these two natural tendencies of all politicians and political actions. All leaders, including Xi Jinping, therefore promote a form of modernisation from the top, which reserves a privileged place for the country's political, economic, and scientific elites, but are also increasingly obliged to display a sincere concern for public opinion (or "popular feeling" to use the Communist jargon). They all carry out opinion polls, the results of which remain secret for the most part. They all have to deal with a growing number of labour disputes. Moreover, increasing numbers of them are developing their own populist tendencies, prime examples being Wen Jiabao (nicknamed Grandfather Wen by the official "masses" and "China's best player" by the critic Yu Jie) and Bo Xilai.

In circumstances such as these and in view of recent developments, it is difficult to class Bo Xilai, the Chongqing Party secretary deposed in March 2012, amongst the elitists: on the contrary, has he not been identified as the most perfect incarnation of contemporary Chinese populism? Conversely, Vice-Premier Li Keqiang would seem more elitist than populist if we consider in particular his less than remarkable career as governor of Henan (during the AIDS-contaminated blood scandal) and Liaoning.

In short, this binary dichotomy gives us little information on the choices and political priorities of future Chinese leaders, in this case $\mathrm{Xi}$ Jinping when he is co-opted as General Secretary and most probably Chairman of the Party Central Military Commission in autumn 2012, then as President of the People's Republic and state CMC Chairman in March 2013. It tells us even less about how much room for manoeuvre he will have in carrying out the political programme currently attributed to him.

\section{Xi: A conservative but flexible moderniser}

We have seen that in carrying out his local and provincial duties, Xi Jinping showed himself to be pragmatic, a moderniser, and even reformist. He has been presented as a defender of the private sector, the market economy, and the large-scale opening up of China to foreign investment, but we have been able to qualify this image. We have also seen that he knows how to be a cautious, orthodox leader, unwilling in his actions, style, and even more so in his private life to depart from the norm authorised by the Party and to expose himself to attacks by his detractors. He presents a clear contrast to someone like Bo Xilai.

From 2007 onwards, as leader of the Secretariat of the Central Committee, he has unhesitatingly applied the political line laid down by $\mathrm{Hu}$ Jintao. He has favoured a collegial style of working with the other members of an authority above all in charge of Party affairs and reform, and dominated by Hu's partisans. In particular, he collaborated closely with LiYuanchao, head of the Organisation Department and principal promoter of a new elite, better trained and more competent, in the Party's upper ranks. He left Liu Yunshan (close to $\mathrm{Hu}$ ), head of Propaganda, to work under the tutelage of $\mathrm{Li}$ Changchun (promoted by Jiang), the principal leader of this sector within the SCPB. And he has worked on a daily basis with Ling Jihua, Hu's former right-hand man and powerful Director of the Central Committee's Department of Ceneral Affairs, the body that controls the distribution of information and official documents. In short, Xi has had no choice but to show loyalty to $\mathrm{Hu}$ and implement his policies.

The same might be said of the role played by Xi in directing the Party's Central School. Nothing he says detracts from Hu's priorities in either ideological or organisational terms. It is true that the project concerning development of the Party's internal democracy (dangnei minzhu) presented by $\mathrm{Hu}$ at the $17^{\text {th }}$ Congress dragged on before being highlighted once again in June 2012 , on the eve and for the requirements of the $18^{\text {th }}$ Congress. But this cannot be seen as a split between $\mathrm{Hu}$ and $\mathrm{Xi}$, since the system remains organised vertically, and the vague movements towards opening it up, also recommended by Xi, notably in Zhejiang, quickly came up against Party rules governing responsibility and promotion. Indeed, in each regional constituency and functional unit, the secretary of the Party Committee remains the "boss" (yibashou), sole beneficiary of the successes, and taking sole responsibility for the failures, in his (or her) area, or dare one say, administrative empire.

More recently, just after the Wang Lijun scandal broke - Wang Lijun being the former head of security in Chongqing who took refuge in the American Consulate at Chengdu in February 2012 and brought about the disgrace of Bo Xilai - Xi used his position as head of the Party School, and the school's journal, Qiushi (Search for Truth), to reiterate Communist principles regarding moral integrity and the fight against corruption. ${ }^{(24)}$ But here again, although we can attribute greater vigilance to $\mathrm{Xi}$ in this domain, he will be obliged to work with a politico-economic reality that affects the families of all Party leaders, including his own. (25)

$\mathrm{X}_{\mathrm{i}}$ is a good organiser and coordinator. He was able to put these talents into practice successfully in 2008 while in charge of preparations for the Beijing Olympic Games. But he is also a leader conscious of the shortcomings and malfunctions of the Chinese bureaucratic system. In recent years he has taken to task local leaders who, "as at the time of the Great Leap Forward" (sic dixit), hid reality and flattered central government leaders

23. That said, Zhou Yongkang is a conservative who was also recommended by his predecessor, Luo Gan, a former member of Li Peng's faction, which probably also satisfied Hu's interests.

24. Speech on the maintenance of the "Purity of the Party" given on 1 March 2012, Qiushi, 15 March 2012. He did it again on 1 August 2012, just a few days after Bo's wife, Gu Kailai, was officially charged with murdering British business man Neil Heywood; Qiushi, 1 August 2012.

25. One of Xi linping's nieces, married to a British national of Italian descent, is director of a Beijing consultancy named Sustainable Innovation Movement, 51SIM, whose activities are directly fed by its proximity to political power. On Xi Jinping's family, see Bloomberg's report, 28 June 2012. 
when they made their tours of inspection. (26) Furthermore, through his own experience and career in several of the country's poor areas, $\mathrm{Xi}$ is more aware than other leaders of the great disparities within China; disparities and backwardness that he does not hesitate to highlight to strengthen his position in international negotiations.

Yet from a political point of view, Xi could in no sense be described as a liberal. This was apparent in Zhejiang and has been even more so since his arrival in Beijing. Following the upheavals of the Arab Spring in early 2011, $X i$ has been closely linked to decisions taken by Party leaders (in particular $\mathrm{Hu}$, Zhou Yongkang, and Li Yuanchao) intended to tighten the authorities' hold over the Internet, NGOs, and society in general. At the end of last year, he even called upon universities to consolidate their "ideological work" with students and strengthen their control over course content. Furthermore, in his eyes, "social harmony and stability" are essential to the further development of economic reforms. It is clear, therefore, that he has never risked following the example of Wen Jiabao or Guangdong Party secretary Wang Yang in their calls for political reform.

This caution can also been seen in the way he plays his part as head of the Party leaders' group with responsibility for the special administrative regions (SAR) of Hong Kong and Macau: in 2007, instead of congratulating himself on the separation of powers that, at least in the former of these regions, constitutes the pillar of rule of law, he gave instructions to the courts to cooperate more closely with Donald Tsang's administration. That said, unlike others, including Liao Hui, former director of the Hong Kong and Macau Affairs Office, Xi in 2010 came out in favour of direct negotiation with Hong Kong's Democratic Party, enabling a cautious step forward (five extra members elected to the Legislative Council, that is to say, 40 out of 70) on the road to political reform in the SAR. (27)

More generally, like the team from which they are preparing to take over, $X i$ Jinping and Li Keqiang are conscious of the need to hasten transformation of the growth model towards an economy stimulated more by internal consumption than by investment and export. It is hard to see any differences between Xi and other Chinese leaders where this general trend is concerned.

There has been a great deal of discussion since the summer of 2011 on the opposition between the Guangdong Model promoted by Wang Yang, whose priority is increasing the size of the "pie," and the Chongqing Model promoted by Bo Xilai, former boss of China's fourth largest municipality, which aims (or aimed) for a fairer distribution of the "pie." Where does Xi stand in this debate? Probably in favour of a synthesis of the two "models," which have more points in common than is often supposed. In line with the Guangdong Model, Xi is trying to improve the quality of the "pie" (upgrading companies and developing green industries), and in line with the Chongqing Model, he shows concern over deepening inequalities and will certainly develop Wen Jiabao's plans to improve and extend social security systems (health, retirement, and unemployment). Unlike Bo, however, he knows that the growth rate of the Chinese economy, still around 8 percent in 2012, can only progressively fall. Unlike Bo, and despite the talents of his wife, he has shown little enthusiasm for bringing revolutionary songs back into favour. Unlike Bo he is reluctant to adopt a crowd-pleasing style and even less so to reintroduce a form of the personality cult. Consequently, although like eight of the nine members of the SCPB - the only exception is Hu Jintao $\mathrm{Xi}$ has made the Chongqing pilgrimage since the arrival of Bo Xilai at its head, he has kept his distance from model and promoter alike. ${ }^{(28)}$ Yet he has shown similar caution with regard to the most innovative experiments of Wang Yang, in particular Wang's management of the Wukan crisis (the dis- missal at the beginning of 2012 of its corrupt leaders, accused of having abusively expropriated villagers' lands and organising new elections), on which Xi has refrained from commenting, at least publicly.

At the international level, $X i$ has gained a wealth of experience in recent years - much more, if measured in the number of trips he has made (47 countries visited), than his predecessor. ${ }^{(29)}$ However, during these official visits, he has sought to emphasise his personal charm rather than original ideas. The substance of his speeches has mostly remained within well-defined limits, coded, or insignificant.

Nonetheless, there have been two unexpected or noticeable exceptions. The first, which occurred in Qatar in June 2008, concerns his answer to questions from Hong Kong journalists on the controversy over the Olympic torch fiasco in France. Xi remained serene, saying he was not too worried about the inevitable criticisms from outside China, which he saw as a largely inoffensive part of the world's "diversity." (30) In short, his answer corresponded to a conflict-avoidance strategy, also recommended, at least until summer 2008, by Hu. The second exception is much better known and more pointed. Addressing the Chinese community in Mexico in February 2009, he declared, "There exist well-fed foreigners who have nothing better to do than criticise our country. China is not exporting revolution, hunger, and poverty. China is giving no one headaches. What more do you want?" (31)

Xi Jinping, nationalist? Most certainly! According to Kuhn, his quasi-official biographer, in Xi's eyes, patriotism and national pride contribute to stimulating development. "Our commitment and determination are anchored in our historic and national pride." (32) Xi will not adopt a low profile on the international stage, confirmation of the distance he is keeping from recommendations made in former years by Deng Xiaoping in the aftermath of Tiananmen (taoguang yanghui).

That said, China's major partners, headed by the United States, are having difficulty identifying any special or original outlook in Xi. His two official meetings with Vice-President Joe Biden (August 2011 in China and February 2012 in the United States) have not helped a great deal, even though Wikileaks has revealed - and it is hardly a surprise - that Xi leans towards cooperation rather than confrontation. ${ }^{(33)}$ Similarly, Japan, which received a visit from Xi in December 2009, is no better informed. On the one hand, Xi insisted on a deviation from Japanese protocol during his visit by requesting and obtaining, in a lapse of time considered much too short, an audience with Emperor Akihito, giving rise to negative rather than positive reactions in the archipelago. On the other hand, in April 2012, following a proposal from the Mayor of Tokyo, the iconoclast Ishihara Shintarô, to buy some of

26. Speech given on 16 November 2011, Renminwang, 21 November 2011, http://politics. people.com.cn/GB/1024/16332666.html (consulted on 14 August 2012).

27. Wu Ming, Xi Jinping zhuan, op. cit., pp. 324 ff.

28. Interview by Cheng Li, "The Bo Xilai Crisis: A Curse or a Blessing for China?", The National Bureau of Asian Research, 18 April 2012; personal interviews. The analysis put forward by Willy Lam in 2010 thus seems to us to be erroneous; see China Brief, vol. 10, no. 21, 22 October 2010, and vol. 10, no. 25, 17 December 2010. Similarly, Wen Jiabao's visit to Chongqing does not imply support for Bo. Nonetheless, after Bo's fall, articles relating to Xi's visit to Chongqing were erased from official sites.

29. According to Robert Kuhn, New Perspectives Quarterly, vol. 29, no. 2, Spring 2012.

30. South China Morning Post (SCMP), 25 June 2008.

31. Chinadigitaltimes.net, 11 February 2009. These pronouncements were quickly erased from official sites in China: SCMP, 14 February 2009.

32. Kuhn, op. cit., p. 4

33. The Diplomat, 18 February 2012, http://thediplomat.com/china-power/wikileaks-on-xi-jinping (consulted on 14 August 2012).

34. Japan Times, 25 April 2012. 
the Senkaku/Diaoyu islands, he saw fit as future leader to add his voice to Chinese warnings to Tokyo on the subject of what he called one of China's "fundamental interests." (34) Lastly, on military and security questions, we are no better informed. Xi has on several occasions praised the integration of the civil and military industries and what Chinese jargon terms "a synthesis of war and peace" (pingzhan heyi), displaying particular interest in the increase in power of the PLA and improvements in the preparation of its members (both active and reservists) and equipment. This position is neither particularly original nor new, yet it allows him to appear a defender of the military institution and strengthens his already numerous links with its leaders. Amongst those close to Xi in the Army, besides Xu Qiliang, the Air Force commander who may take over the Vice-Chairmanship of the CMC, there is Ma Xiaotian, Chief of Staff in charge of information; Liu Yuan (son of Liu Shaogi, former Chinese president), political commissioner of the General Department of Logistics; and Zhang Haiyang (son of General Zhang Zhen), political commissioner of the Second Artillery (strategic forces and missiles). The last three are also princelings who will be called upon, if they succeed in distancing themselves from Bo Xilai, to accede to the CMC during the CCP's $18^{\text {th }}$ Congress. ${ }^{(35)}$ This shortage of information does not mean that Xi lacks charisma. On the contrary, if a major difference between Xi and Hu exists, it is certainly that unlike his predecessor, when he enters an assembly, $\mathrm{Xi}$ makes his presence felt immediately. He smiles and is expressive, warm, and communicative. He gives the impression of being human, made of flesh and blood, a person with feelings, tastes, and preferences rather than a robot or prison door. He is, moreover, a far better communicator than his predecessor.

This does not tell us what Xi will do once he comes to power, however. As we have seen, like Hu when he advanced in the shadow of Jiang, he has too often avoided taking an original stance on any subject whatsoever. However, the system lends itself to this and it would be wrong to draw too many conclusions one way or another on the basis of our knowledge of the declarations or past actions of $\mathrm{Xi}$ Jinping. Admittedly, unlike $\mathrm{Hu}$, Xi belongs to a family reputedly more reformist than that of Bo Yibo or of Zhang Zhen, former vice-chairman of the CMC. For example, unlike Bo Xilai's father, Xi Zhongxun defended Hu Yaobang when the latter was stripped of his functions in January 1987 after the previous month's student demonstrations. $\mathrm{He}$ is also said to have criticised the Tiananmen repression in 1989. (36) However, we may cautiously wager that $\mathrm{Xi}$ is a conservative but flexible moderniser, and therefore capable, up to a certain point, of adapting to circumstances that are by definition unpredictable.

\section{Constraints on the future of Xi as Number One}

Two types of constraints are likely to seriously limit Xi's room to manoeuvre in a way that is currently uncertain: the first are institutional and political, while the second are social and potentially political.

\section{Institutional and political constraints}

Since Deng Xiaoping's death, the Chinese political system has evolved towards a form of authoritarianism whose principle of group directorship has exacerbated fragmentation. If we take stock of the Hu years, we might reach the conclusion that Hu proved to be a more consensual primus inter pares and consequently weaker and more indecisive than his predecessor. When forced to take a sensitive decision, Hu frequently took refuge in a cautious wait-and-see strategy, leaving the SCPB to settle matters on a majority basis once Party veterans had been duly consulted. He also more often let local leaders try out their own solutions. There is no lack of examples, but the Bo Xilai affair is a recent and eloquent illustration of Hu's inability to put an end to a tendency that Party leaders had long known was dangerous.

$\mathrm{Xi}$ Jinping must therefore not only consolidate his power as number one, notably through the promotion of a certain number of protégés in the years to come, but also be capable of imposing his decisions when necessary. Will he have the means to do this?

Up until now, Xi has not had to settle or handle a political, economic, social, or international crisis from a front-line position. He has, for example, remained very discreet on the Bo Xilai affair. Consequently, his abilities in such situations have not been put to the test. His capacity to surmount these trials will not depend solely on his talents as an organiser or even on the charisma he is reputed to have. It will depend on his skill in building a fairly solid political coalition to negotiate such crises.

However, Xi will have to work with a team co-opted mainly by Hu Jintao and to a lesser extent by jiang Zemin and his allies. It is true that the Bo Xilai affair has weakened the neo-conservative camp that sought to consolidate the role of the public sector and return to a type of Maoism. Furthermore, the Politburo will doubtless gain a greater number of reformists, including Wang Yang, who is expected to join the SCPB, and Secretariat member Wang Huning, a former academic from Shanghai University who may take charge of Foreign Affairs. ${ }^{(37)} \mathrm{Xi}$ may also benefit from a shrinking of the SCPB from nine to seven members, and the possible exclusion from the Politburo of the most powerful provincial leaders, if rumours circulating in Beijing and Hong Kong in early 2012 are confirmed. ${ }^{(38)} \mathrm{A}$ smaller SCPB is better able to make decisions and reach consensus, and if the security apparatus is weakened when no longer represented, the same logic would apply to the leaders of the major municipalities (Beijing, Shanghai, Tianjin, and Chongqing) and provinces (such as Cuangdong), which were until the $18^{\text {th }}$ Party Congress represented in the Politburo. However, most other potential members of this collective leadership will be former protégés of $\mathrm{Hu}$, including Li Keqiang, LiYuanchao, probably Liu Yunshan (head of the Secretariat and director of the Party's School, then Vice-President of the Republic) in charge of ideology, and Liu Yandong, ${ }^{(39)}$ who will take over the Chairmanship of the CPPCC. Only the Secretary of Shanghai, Yu Zhengsheng, who may direct the NPC, and Wang Qishan, probable future Number Two in the government, although promoted by $\mathrm{Hu}$, seem less close to Xi and more reformist.

One last important issue is clearly the question of the CMC chairmanship. Up until recently, most observers (myself excepted) favoured repetition of the Jiang Zemin precedent, by which the former leader would retain control of this authority for two more years after leaving his position as Party head

35. China Brief, vol. 11, no. 16, 2 September 2011; SCMP, 24 April 2012 (see below). Apparently, Zhang Haiyang, political commissioner of the military region of Chengdu between 2005 and 2009, was implicated in dubious land transactions along with Bo Xilai and excluded from promotion. Liu Yuan's promotion was not affected. See The Wall Street Journal, 17 May 2012, http://online.wsj.com/article/SB10001424052702304203604577398034072800836.html (consulted on 14 August 2012).

36. The Wall Street Journal, 18 October 2010 ; Kuhn, op. cit., p. 63.

37. To succeed Dai Bingguo, Wang Huning would be in competition with the Minister of Foreign Affairs, Yang Jiechi.

38. Reuters, 11 May 2012. Interviews, Beijing and Hong Kong, April-June 2012.

39. Liu Yandong, close to both jiang and $\mathrm{Hu}$, is the daughter of a former Vice-Minister of Agriculture, Liu Ruilong. She could become the first woman to join the CPPB. 
(from 2002 to 2004). The explosion of the Bo Xilai affair is thought to have precipitated things and to have led to a form of bargaining between Jiang Zemin and $\mathrm{Hu}$ Jintao: in exchange for Bo Xilai's head, Hu would lose that of the CMC! (40) The dual logic of this aggiornamento is clear. On the one hand, the management would regain a united façade by cutting off the rotten branch embodied by Bo, his wife Gu Kailai, accused of murder, and their respective families. On the other, $\mathrm{Xi}$ would begin his mandate (in principle, five years renewable once) in a stronger position than his predecessor.

The resultant sidelining of security chief Zhou Yongkang, said to be very close to Bo Xilai (but who has formally continued his duties and retained his place within the SCPB, probably until the $18^{\text {th }}$ Congress), and the information we have gathered on the latter's power-taking strategy with the possible help of Zhou - including tapping the phones of $\mathrm{Hu}$ Jintao and other central leaders - shows that they increase the risk of political instability in China and the uncertainties weighing on the future of $\mathrm{Xi}$ jinping. These are all questions that will be added to the social, and potentially political, challenges that the Chinese authorities will have to face in the years to come.

\section{Social and political challenges}

For Xi Jinping, Bo's downfall is clearly a poisoned chalice. This unexpected event could allow Xi to consolidate his power more rapidly than expected, in particular if Hu leaves the field open to him or gives him his support. Besides, Bo's purge has removed a challenger from amongst the leaders, another no less ambitious princeling, suspected of wanting to defy Xi after one or two years in the SCPB by taking advantage of his own links with the Army and security bodies. For Xi, it would be better that the boil is lanced before, rather than after, the $18^{\text {th }}$ Congress.

However, Xi is taking over the post of General Secretary at a particularly sensitive moment. The Party leadership is divided. The reformists, led by Wen Jiabao, want to push their advantage and launch political reform, the exact content of which is unknown but which has been disparaged by the conservatives. Labour unrest is increasing. Economic development is slowing down whilst the implementation of a new growth model is far from guaranteed. By uncovering an unprecedented quantity of information on the abuse of privilege and on wide-ranging corruption in the upper echelons of the Nomenklatura, the Bo Xilai scandal has seriously challenged the legitimacy of the CCP and has consequently tarnished the image of all the princelings, of which $X_{i}$ is also an important representative and to which, according to Wikileaks, Xi himself attributes a vital historic role. ${ }^{(41)}$ Lastly, the position of the reformists and that of $X i$ have been strengthened by the cooperative role played by the Obama administration in the current transition. Not only did the US help the Chinese authorities deal with the Bo Xilai crisis by delivering Wang Lijun to the central bodies of Chinese security and observing a code of silence on what they obtained in terms of confidences, ${ }^{(42)}$ but later in the spring, in April-May 2012, it did all it could to favour a positive outcome for the diplomatic crisis brought about by the flight of the blind dissident Chen Guangcheng from a village in Shandong where he was held, quite illegally and against his wishes, before being transferred in extraordinary circumstances to the United States Embassy in Beijing with the help of underground Protestant networks that are more powerful than the authorities imagine. For the nationalists, these two crises have contributed to weakening the status and prestige of the Chinese government in the face of its ideological and strategic enemies headed by the United States. What is more, these nationalists have not accepted their pro- visional defeat any better than the Party conservatives and other partisans of Bo Xilai and Zhou Yongkang.

\section{Conclusion}

Consequently, $\mathrm{Xi}$ Jinping will need the full support of the outgoing team and in particular of $\mathrm{Hu}$, Wen, the PLA, and the security apparatus in order to succeed. The weakening of the conservative camp and the necessity for reforms will help, as will the provinces that have already embarked on at least some of the structural measures that China must now implement on the advice of the government's reformists and following the recommendations of the World Bank. However, China is undoubtedly entering a zone of deeper political uncertainty, if not upheaval. Xi will therefore need to bring into play all the talents we know him to possess - or that have been attributed to him - to succeed in leading the world's second largest economy towards a political, institutional, and legal environment that is more in tune with the expectations of its population and the international community. He will also have to be capable of maintaining his control both over the processes already in motion and the social fabric as a whole. In the years to come, the role of the security forces and the military is highly likely to increase rather than diminish, and their submission to the Party will become even more of a vital issue. Lastly, and above all, we must not forget that in presiding over the destiny of a society in rapid transformation, Xi will doubtless be forced, depending on circumstances, to take decisions and introduce reforms to which he is currently opposed, or even some that he cannot at present imagine. According to Wikileaks, Xi has said that his experience in the north of Shaanxi during the Cultural Revolution taught him "to face up to all challenges, believe in the impossible and overcome all obstacles without panicking." (43) Will he prove worthy of the task that awaits him? Perhaps, but only perhaps.

\section{Translated by Elizabeth Guill.}

I Jean-Pierre Cabestan is Professor \& Head, Department of Government and International Studies, Hong Kong Baptist University; Associate Research Fellow, Asia Centre, Paris; and Associate Research Fellow, French Centre for Research on Contemporary China, Hong Kong (cabestan@hkbu.edu.hk).

40. Quoted by Boxun, 19 April 2012, http://www.wantchinatimes.com/news-subclasscnt.aspx?id=20120419000076\&cid=1101 (consulted on 14 August 2012)

41. The Diplomat, op. cit.

42. American diplomats subsequently provided an increasing number of details on the Bo affair and the negotiations over the future of Chen Guangcheng to the American press, however.

43. The Diplomat, op. cit. 